\title{
Short Communication: Lack of differentiation within the bigeye tuna population of Indonesia
}

\author{
NI PUTU DIAN PERTIWI ${ }^{1}$, BUDI NUGRAHA ${ }^{2}$, RIRIK KARTIKA SULISTYANINGSIH ${ }^{2}$, \\ IRWAN JATMIKO ${ }^{2}$, ANDRIANUS SEMBIRING ${ }^{1}$, ANGKA MAHARDINI ${ }^{1}$, NI KADEK DITA CAHYANI ${ }^{1}$, \\ AJI WAHYU ANGGORO ${ }^{1}$, HAWIS H. MADDUPPA ${ }^{4}$, AMBARIYANTO AMBARIYANTO ${ }^{5}$, \\ PAUL H. BARBER ${ }^{6}$, GUSTI NGURAH MAHARDIKA ${ }^{1,7, \bullet}$ \\ ${ }^{1}$ Indonesian Biodiversity Research Center. J1 Sesetan-Markisa 6, Denpasar 80226, Bali, Indonesia. Tel.: +62 3618423062 , Fax: +62 361 223 791, \\ "email: gnmahardika@unud.ac.id \\ ${ }^{2}$ Tuna Fisheries Research Center, The Ministry of Marine and Fisheries Affairs, Denpasar, Bali, Indonesia \\ ${ }^{4}$ Department of Marine Science and Technology, Institut Pertanian Bogor. J1. Agatis No 1, Darmaga, Bogor 16680, West Java, Indonesia \\ ${ }^{5}$ Department of Marine, Faculty of Fisheries and Marine Science, Universitas Diponegoro. Tembalang, Semarang City 50275, Central Java, Indonesia \\ ${ }^{6}$ Department of Ecology and Evolutionary Biology, University of California Los Angeles, Los Angeles, CA 90095-7239, USA \\ ${ }^{7}$ Laboratory of Animal Biomedical and Molecular Biology, Universitas Udayana. J1 Sesetan-Markisa 6, Denpasar, Bali, Indonesia
}

Manuscript received: 13 June 2017. Revision accepted: 2 September 2017.

\begin{abstract}
Pertiwi NPD, Nugraha B, Kartika R, Sulistyaningsih RK, Jatmiko I, Sembiring A, Mahardini A, Cahyani NKD, Anggoro AW, Madduppa HH, Ambariyanto A, Barber PH, Mahardika GN. 2017. Short Communication: Lack of differentiation within the bigeye tuna population of Indonesia. Biodiversitas 18: 1406-1413. All highly migratory tuna and tuna-like species have vast feeding grounds and spawning grounds. Indonesia's tuna catch is the largest in the world. However, genetic diversity in the population structure within particular tuna species in Indonesia is very limited. Here we provide genetic data for bigeye tuna (Thunnus obesus) covering fishing grounds and local fish markets throughout Indonesia. A fragment of mitochondrial DNA in the D-loop control region was amplified from samples collected across Indonesia in the biennium 2012-2013. The results showed high haplotype diversity and low nucleotide diversity in our samples. Little differentiation occured between the eleven diverse sampling locations, nor was any separation detected between general regions of Indonesia, nor between samples from fishing grounds and samples from fish markets.
\end{abstract}

Keywords: Bigeye tuna, mtDNA, Indonesia

\section{INTRODUCTION}

Having extensive archipelagic waters and an exclusive economic zone of 200 nautical miles, Indonesia should play a central role in maintaining the world's pelagic and coastal biomass. This country's seas are the migratory route, nursery and spawning ground for various species, including tuna. Indeed, tuna and their relatives are found in abundance here (Juan-Jorda et al. 2013), providing a significant source of income for Indonesia (FAO Fisheries 2013). Benefiting from this abundance, Indonesia is the biggest tuna-producing country in the world, contributing $15 \%$ to global tuna production in 2009 (Miyake et al. 2010; Sunoko and Huang 2014).

Genetic data should be incorporated in management models in order to develop more realistic conservation strategies. Genetic data for tuna fisheries is of particular interest. Many of the world's tuna populations have dwindled by up to $60 \%$ from 1950 's levels, as the industry has increased. The long life-cycle of tuna has exacerbated this trend (Collette et al. 2011; Juan-Jorda et al. 2011). If current exploitation rates continue, it is estimated that the bigeye tuna population of the Central and Western Pacific will soon reach a stock level that will be incapable of producing maximum sustainable yields (Sibert et al. 2012).
To our knowledge, there is very limited population genetic data for tuna caught in Indonesia. While Indonesian-wide scientific coverage of the population genetics of other species, such as frigate tuna, kawakawa, skipjack tuna, Indian mackerel, and narrow-barred Spanish mackerel has been well documented (Jackson et al. 2014), genetic information is scarce for the principal market species of tuna - bluefin, yellowfin and bigeye. Therefore, in the research reported here, we examined genetic variability of bigeye tuna in the western, central, and eastern Indonesia waters using mitochondrial control region sequence data. This particular marker has been shown to be particularly sensitive in detecting the population genetic structure of marine migrating and predatory fish (Buonnacorsi et al. 2001).

\section{MATERIALS AND METHODS}

\section{Sample collection}

Fin clips of bigeye tuna samples were collected across Indonesia in 2012-2013, including in (1) Aceh, (2) Indian Ocean high sea, off-shore west of Sumatra (Bungus Island), (3) Pelabuhan Ratu (West Java), (4) Muara Baru, (5) Indian Ocean high sea, off-shore south of Java Island, (6) Lombok, (7) Bone (South Sulawesi), (8) Bitung (North 
Sulawesi), (9) Ternate (North Maluku), (10) Ambon, and (11) Manokwari (West Papua). All locations are shown in Figure 1. The number of samples from each of the 11 locations, the general region of Indonesia represented, and the type of sample (originating either from a fishing ground or a fish market) are listed in Table 1.

Each fin clip was collected and preserved in ethanol 95\%. Genomic DNA was extracted using a 10\% Chelex solution (Walsh et al. 1991). The control region (CR) mtDNA fragment was amplified using polymerase chain reaction (PCR) with the published CRK-CRE primers (Lee et al. 1995). Following visualisation of PCR products on $1 \%$ agarose gels stained with ethidium bromide, the PCR products were sequenced using both PCR primers using the Big Dye Chain Termination protocol at the University of California Berkeley Sequencing Facility.

Population genetic analyses (haplotypic diversity $(\mathrm{H})$, nucleotide diversity $(\pi)$, index $\Phi_{\mathrm{ST})}$ were executed using Arlequin ver.3.5 (Excoffier and Lischer 2010) and DnaSP 5.1 (Librado and Rozas 2009). Samples from Aceh were not included in the population comparison due to a limited number of samples. Delineative statistics such as haplotypic diversity $(\mathrm{H})$ (Nei et al. 1985) and nucleotide diversity $(\pi)$ (Lynch and Crease 1990) were determined for each sampling location, for geographic regions, as well as for the type of sample (originating from fishing grounds or fish markets). The inter-haplotype levels of divergence were estimated using the index $\Phi_{\mathrm{ST}}$ (Excoffier et al. 1992), which includes information on mitochondrial haplotype frequency (Weir and Hill 2002) and genetic distance (Tamura and Nei 1993). The analysis of molecular variance (AMOVA) (Excoffier et al. 2005) was used to examine the amount of genetic variability partitioned within and among populations. Permutation procedures $(n=20.000)$ were used to construct null distributions and to test the significance of variance components for each hierarchical comparison (Guo and Thompson 1992).

Phylogeny was reconstructed using the NeighborJoining method (Saitou and Nei 1987). The evolutionary distances were computed using the Kimura 2-parameter method (Kimura 1980). The test of phylogeny was conducted using the bootstrap method with 1000 replicates. Evolutionary analyses were conducted in MEGA6 (Tamura et al. 2013). Included in the analysis were bigeye tuna (BET) reference accessions with the following accession numbers: AY640276-288 from East Atlantic and AY640299-301 from Western Pacific, South China Sea, and the Philippines (Chiang et al. 2006) as well as EF154397-417 from Indian Ocean off Seychelles, off-shore Southwestern and Southeastern India, as well as Cocos Islands (Chiang et al. 2008).

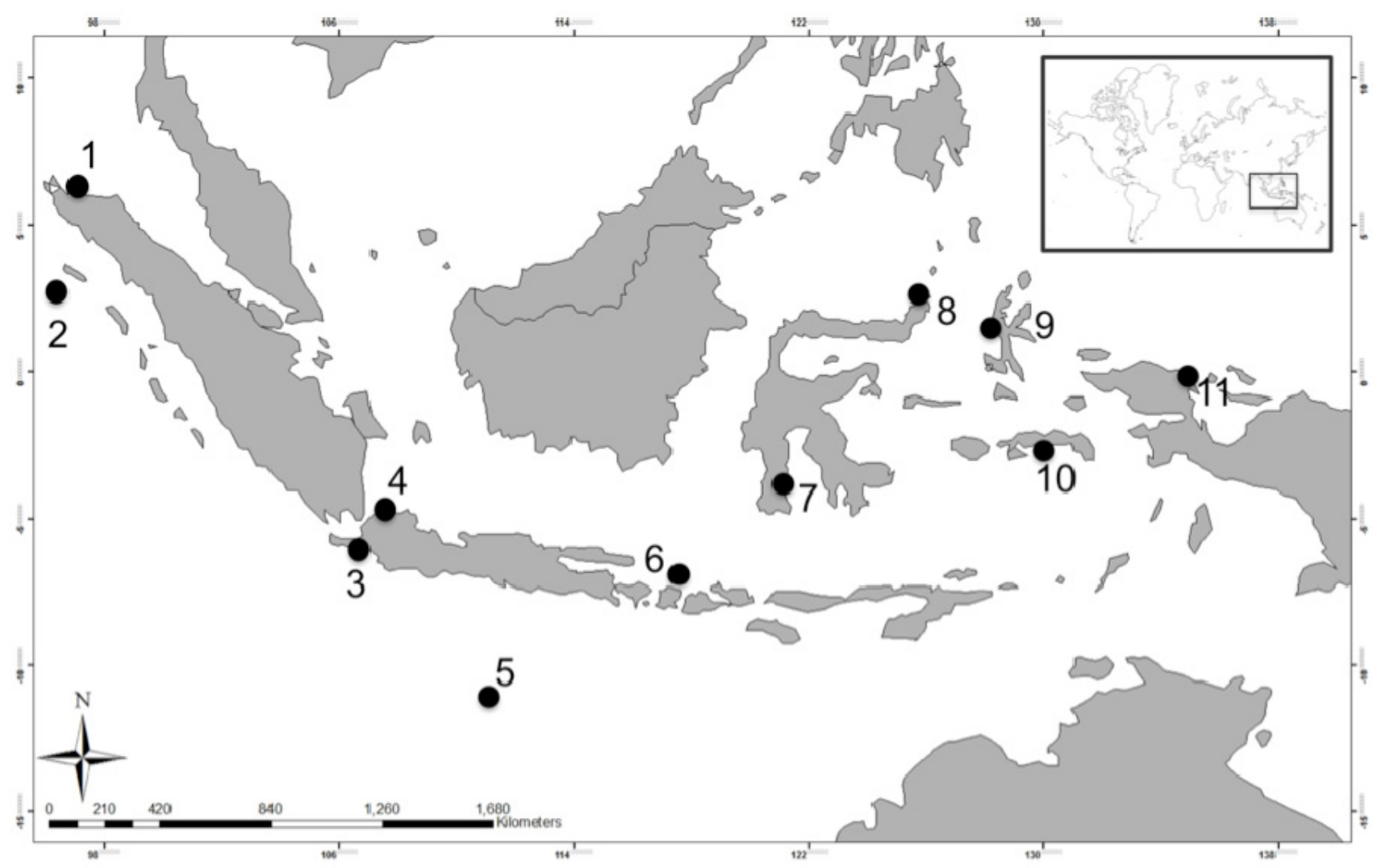

Figure 1. Map of Indonesia showing sampling locations for bigeye tuna (Thunnus obesus) coded by black circle. No 1 to 11 indicated each locations, (1) Aceh, (2) Indian Ocean high sea, off-shore west of Sumatra (Bungus Island), (3) Pelabuhan Ratu (West Java), (4) Muara Baru, (5) Indian Ocean high sea, off-shore south of Java Island, (6) Lombok, (7) Bone (South Sulawesi), (8) Bitung (North Sulawesi), (9) Ternate (North Maluku), (10) Ambon, (11) Manokwari (West Papua) 


\section{RESULTS AND DISCUSSION}

\section{Haplotype (H) and nucleotide diversity $(\pi)$}

A total of 414 CR-mtDNA sequences for bigeye tuna were analysed in the study, based on a well-defined sequence of $447 \mathrm{bp}$. All sequence data has been deposited in GenBank with the following Accession Numbers: KR105968-KR106131 and KM871869-KM872030. The number of haplotypes $(\mathrm{NH})$, the haplotype diversity $\left(\mathrm{H}_{D}\right)$ and the nucleotide diversity $(\pi)$ estimated for each of the 11 sampling locations, for each region (West, Central or East) of Indonesia, and for the two type of sampling sites (fishing ground or fish market) are presented in Table 1. The results show that bigeye tuna possesses high haplotype and low nucleotide diversity throughout Indonesia. The lowest $\mathrm{H}_{D}$ was in Lombok (0.981), while the highest (1.00) was found in Aceh, Bungus, South Sulawesi, and Papua. The $\mathrm{H}_{D}$ 's in west, center, and east Indonesia were 0.999, 0.998 and 0.997, respectively. Based on the type of sampling location, the $\mathrm{H}_{D}$ 's in the fishing ground and fish market were 0.997 and 0.998 . The overall value for nucleotide diversity $(\pi)$ across locations was only $0.028 \pm 0.003$.

\section{Analysis of molecular variance (AMOVA)}

The result of the analysis of molecular variance (AMOVA) of CR-mtDNA from various sampling locations is shown in Table 2. Population comparison between sampling area is shown in Table S1. Group comparisons based on the geographic area of Indonesia (west, center, and east) and the nature of sampling site (fishing ground and fish market) is summarized in Table 3. Overall fixation index (FST) was 0.00391. This index indicates there was no significant differentiation between bigeye sampling locations. Group comparisons resulted in no significant differentiation between geographic parts of Indonesia (west, center and east) and between the types of sampling locations (fishing ground and fish market). Population comparison between locations (Table S1) shows significant differentiations between Lombok and Ambon as well as between North Sulawesi's and North Maluku's bigeye samples.

Table 1. Origin, total number of readable sequences, number of haplotypes $(\mathrm{NH})$, haplotype diversity $(\mathrm{H})$ and nucleotide diversity $(\pi)$ of bigeye and yellowfin tunas from various sampling locations, geographic part of Indonesia, as well as two types of sampling sites

\begin{tabular}{lcccc}
\hline \multirow{2}{*}{ Origin } & \multicolumn{4}{c}{ Delineative statistics } \\
\cline { 2 - 5 } & No. Seq\# & NH & $\mathbf{H}_{\boldsymbol{D}}$ & $\boldsymbol{\Pi}$ \\
\hline Aceh & 3 & 3 & 1 & 0.026 \\
Indian Ocean Bungus & 19 & 19 & 1 & 0.028 \\
West Java & 67 & 65 & 0.999 & 0.029 \\
Muara Baru & 47 & 40 & 0.994 & 0.027 \\
Indian Ocean Java & 36 & 33 & 0.995 & 0.028 \\
Lombok & 15 & 13 & 0.981 & 0.031 \\
South Sulawesi & 25 & 25 & 1 & 0.028 \\
North Sulawesi & 126 & 103 & 0.996 & 0.029 \\
Ambon & 21 & 20 & 0.995 & 0.025 \\
North Maluku & 41 & 37 & 0.995 & 0.024 \\
Papua & 14 & 14 & 1 & 0.033 \\
West Indonesia & 89 & 86 & 0.999 & 0.029 \\
Centre Indonesia & 249 & 200 & 0.998 & 0.027 \\
East Indonesia & 76 & 68 & 0.997 & 0.026 \\
Fishing Ground & 55 & 51 & 0.997 & 0.028 \\
Fish Market & 359 & 279 & 0.998 & 0.026 \\
\hline
\end{tabular}

Table 2. Analysis of molecular variance (AMOVA) of mtDNA control region of Bigeye tuna from various sampling locations

\begin{tabular}{lcccc}
\hline Source of variation & DF $^{*}$ & Sum of squares & Variance component & Percentage of variation \\
\hline Among population & 9 & 66.796 & $0.02535 \mathrm{Va}$ & 0.39 \\
Within-population & 401 & 2587.214 & $6.45191 \mathrm{Vb}$ & 99.61 \\
Total & 410 & 2654.01 & 6.47725 & \\
Fixation Index (FST) $=$ & & 0.00391 & & \\
\hline
\end{tabular}

Note: *: Aceh data was excluded from the analysis

Table 3. Group Comparison based on geographic area of Indonesia (west, center and east) and the nature of sampling sites (fishing ground and fish market) of bigeye tuna

\begin{tabular}{lcccc}
\hline \multicolumn{1}{c}{ Structure tested } & \multicolumn{2}{c}{ Observed partition } & \\
\cline { 2 - 5 } & Variance & \% total & $\boldsymbol{\Phi}$ statistics \\
\hline & & & & \\
Based on geographical regions (West, Center, and East Indonesia) & 0.02278 & 0.35 & 0.00352 & 0.06648 \\
Among regions & 0.00372 & 0.06 & 0.00058 & 0.37454 \\
Among locations within regions & 6.44801 & 99.59 & 0.00409 & 0.1375 \\
Within locations & & & \\
Based on type of sampling locations (fishing ground, and fish market) & & & \\
Among sample types & 0.0135 & 0.21 & 0.00209 & 0.78459 \\
Among locations within sample types & 0.02256 & 0.35 & 0.00349 & 0.11178 \\
Within locations & 6.44801 & 99.86 & 0.00140 & 0.13975 \\
\hline
\end{tabular}




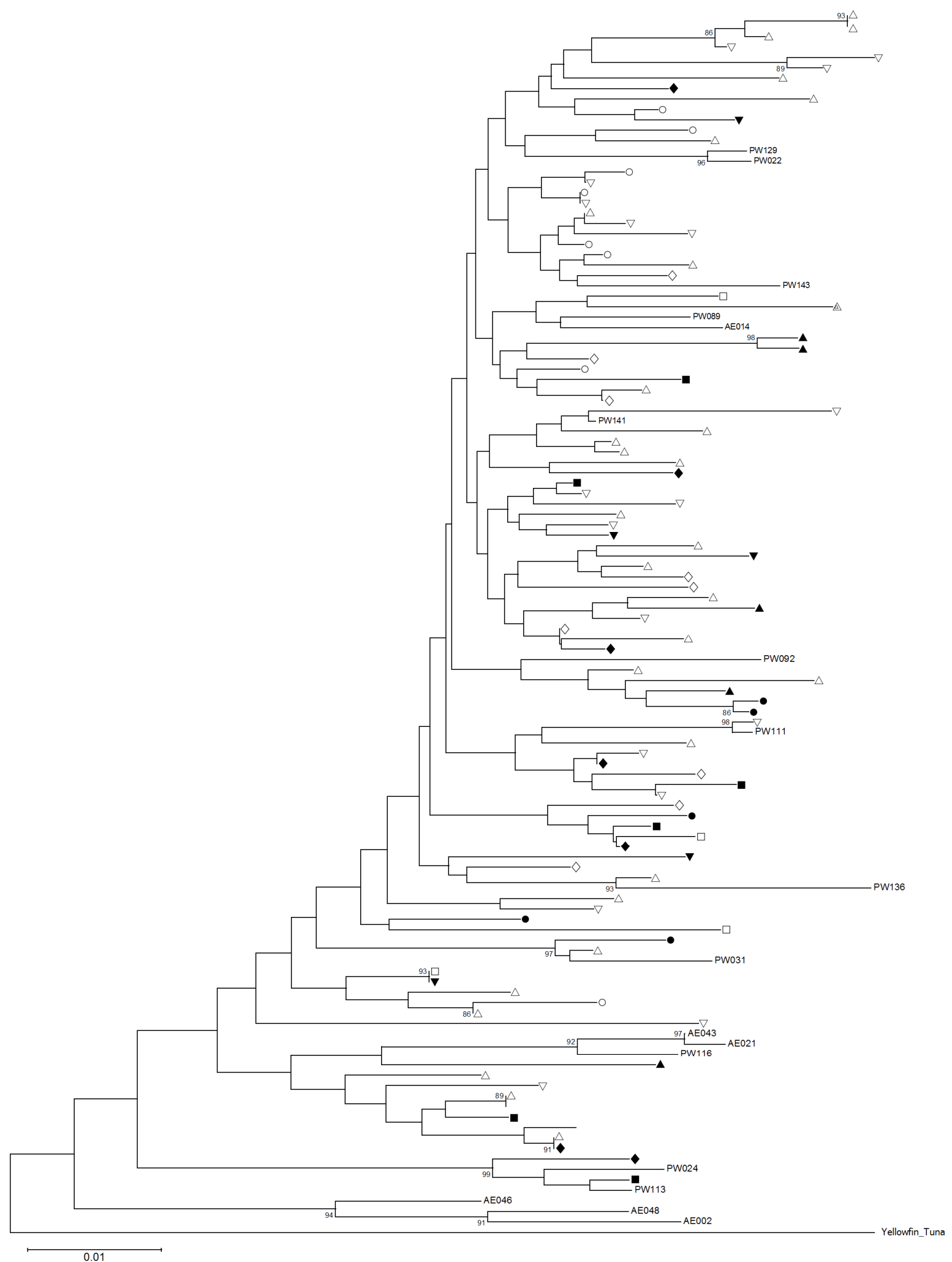

Figure 2. Neighbor-Joining tree of mtDNA control region fragment of bigeye tuna from various locations in Indonesia co-analyzed with secondary data available in GenBank from West Pacific, East Atlantic, and the Indian Ocean as previously published (Chiang et al., 2006, 2008). The taxon markers were filled inverted triangle for samples from Aceh, filled triangle from Bungus, unfilled inverted triangle from West Java, filled diamond from Muara Baru, unfilled circle from Java-Indian Ocean, filled circle from Lombok, filled square from South Sulawesi, unfilled triangle from North Sulawesi, unfilled square from Ambon, and unfilled diamond from North Maluku. The secondary data are indicated as PW and AE from the Indian Ocean, West Pacific, and East Atlantic. The evolutionary history was inferred using the Neighbor-Joining method (Saitou and Nei 1987). Test of phylogeny was conducted using the bootstrap method with 1000 replicates. Bootstrap values of $\geq 80 \%$ are shown. A yellowfin tuna sequence (Acc. No. KP299042) was analysed as an outgroup 


\section{Evolutionary relationships}

Evolutionary relationships for the mtDNA control region fragment of bigeye tuna from Indonesia were coanalyzed with data from Atlantic, Western Pacific and the Indian Ocean beyond Indonesia is shown in Figure 2. The phylogenetic tree shows that most of the Indonesian data belong to a single clade along with some Western Pacific and Indian Ocean East Atlantic data. A minor clade exists together with PW024 and PW113 secondary data (bootstrap value of $99 \%$ ).

\section{Discussion}

We found that bigeye tuna in Indonesia seas possess high haplotype diversity and low nucleotide diversity based on analysis of a CR-mtDNA marker in populations sampled throughout the archipelago. Tuna is known as a highly migratory cosmopolitan marine fish (FAO 2000) and the origin of all species is thought to be polyphyletic (Kumar et al. 2014). Little migration occurs between Atlantic and Pacific-Indian Oceans for bigeye tuna (Chiang et al. 2006, 2008; Gonzalez et al. 2008). The fish are believed to possess large population sizes, that lead to the observed slow genetic drift with low-level or even no differentiation between Indo-Pacific and the Atlantic (Gonzalez et al. 2008).

Having vast inter-island waters, we expected some genetic differentiation among bigeye tuna. However, we found no differentiation between sampling locations, geographic regions (west, center, and east of Indonesia), and none between the types of sampling site (fishing ground and fish market). In the AMOVA between locations (Table S1), a significant difference was detected between Lombok and Ambon as well as between North Sulawesi and North Maluku. This small population differentiation might be due to the seasonal movement and age of tunas. The samples from those sites were mostly of young bigeye tuna collected from fish markets. This seems to be the harvest of traditional fishermen and artisanal fisheries. The artisanal tuna fisheries are most likely operating near shore and in inter-island waters or by using anchored fish aggregating devices (FAD) like 'payaos' in the Philippine (Dickson and Natividad 2000; Macusi et al. 2015). This traditional fishery might catch mostly baby tuna.

Many biological aspects of tuna are still unknown, especially regarding spawning and baby tuna. Adult bigeye tuna are known to be mesopelagic and mid-ocean species (Guojon and Majkowski 2000). Some tuna species, such as bluefin and yellowfin are known to exhibit homing behavior, returning to a specific place to spawn (Guojon and Majkowski 2000). Information for bigeye is lacking. This species might exhibit this behavior too. Further study is needed to explain the population differentiation found in some places, perhaps by simply analyzing samples of baby tuna.

The overall finding of our study is that there is a single population of bigeye tuna in Indonesia. This finding is in agreement with previous reports. Using CR-mtDNA, Chiang et al. (2008) confirmed the presence of various clades of bigeye, with the Atlantic clade limited in distribution to the Atlantic, and clades I and III dispersed in the Western Pacific, Indian Ocean, and Atlantic. No representatives of the Atlantic clade was identified in our study, as the reference accessions for the Atlantic clade (AE002, AE046 and AE048) formed a distinct cluster with bootstrap value of $94 \%$ (Figure 2).

Single dominant lineage has been identified in the South China Sea, Philippine Sea and Western Pacific Ocean, while minor clades are found in all waters (Chiang et al. 2006). A minor clade was also identified in this study from Indonesia (Figure 2). The demarcation of the specific Atlantic clade from the Pacific-Indian-Atlantic Oceans shared clade has been demonstrated using nucleotide sequencing from the same gene fragment used in our study (Martinez et al. 2006), as well as using random fragment length polymorphism (Chow et al. 2000). A barrier to gene flow at the Cape of a Good Hope, South Africa, has been proposed (Alvarado-Bremer et al. 1998; Chow et al. 2000). However, using data from nuclear microsatellite loci, Gonzalez et al. (2008) infered that bigeye tuna is a single worldwide panmictic unit The lack of congruence between $\mathrm{mt}$ and nDNA is thought to reflect past events of isolation and secondary contact (Gonzalez et al. 2008). The presence of representatives of the Pacific-Indian Ocean clade in the Atlantic is predicted based on hypothesized extensive migrations before the last glaciation. The discrepancy between $\mathrm{mt}$ and nDNA might also reflect behavioral differences between sexes such as female-biased philopatry and male-biased dispersal (Qiu et al. 2013).

This is the first spatial data covering Indonesia for bigeye tuna. The inference made in this study was based on a single mtDNA marker, the polymorphic control region, CR (Brown et al. 1986). This marker was selected in order to make a direct comparison with the global population data for tuna, as most other studies have targeted this fragment (Chiang et al. 2006, 2008). Using CR-mtDNA does have an advantage compared to other loci such as $\mathrm{COI}$, as the coding regions are mostly under positive selection and accommodate viable mutations only. Therefore, greater variation occurs in CR compare to other coding regions. The weakness of CR-mtDNA is the lack of concordance with the results of using nuclear microsatellite loci (Gonzalez et al. 2008) in bigeye tuna. The discrepancy might reflect behavioral differences of male and female fishes (Qiu et al. 2013). Despite reservations about results obtained from different methods, the lack of differentiation we found amonst the bigeye tuna populations mirrors similar responses to evolutionary processes and biogeographic events observed in various comparable taxa (Carpenter et al. 2011).

The results of this study might reflect the high population size for bigeye tuna. Further study needs to be carried out concerning the temporal or seasonal population structure for this species. The techniques we have applied in this study have been made available within the country and will benefit government agencies in the responsible management of the tuna industry. Good quality fisheries data needs to be collected regularly - such as hook rates, voyaging distances, fishing grounds, fork lengths, maturity 
levels and trends in cost per kilogram. This is required in order to provide a better understanding of the status of the tuna stocks and the strength of the fishery. This will allow decisons to be made on various management parameters such as maximum sustainable yields, and perhaps in the future total allowable catch levels.

In conclusion, the bigeye tunas catch in Indonesia has high haplotype diversity and low nucleotide diversity. Little population differentiation occurs between specific sampling locations, between geographic regions, and between types of samples taken to assess this diversity. Indonesian seas support a population of bigeye tuna assigned to the major Pacific and Indian Oceans clades for the species. Temporal differentiation needs to be examined in future studies, together with fisheries data, to generate a complete picture of the status of the tuna industry and to identify management actions needed to sustain the fishery for the benefit of peoples' livelihoods as well as the country's income.

\section{ACKNOWLEDGEMENTS}

We gratefully acknowledge several sources of institutional, private and corporate financial support for this study, which was a project of the Partnerships for Enhanced Engagement in Research (PEER) Science Program (AID-OAA-A-11-00012) funded by the United States Agency for International Development (USAID) and the National Science Foundation (NSF), in partnership with NSF PIRE grantee Prof. Kent E Carpenter, ODU-VA (award OISE- 0730256). Facilities for this study were provided by UCLA and the Smithsonian Institution under USAID Grant No: 497-A-00-10-00008-00. All authors declare no actual or potential conflict of interest.

\section{REFERENCES}

Alvarado-Bremer JR, Stequart B, Robertson NW, Ely B. 1998. Genetic evidence for inter-oceanic subdivision of bigeye tuna (Thunnus obesus Lowe) populations. Mar Biol 132: 547-557.

Brown GG, Gadaleta G, Pepe G, Saccone C, Sbisa E. 1986. Structural conservation and variation in the D-loop-containing region of vertebrate mitochondrial DNA. J Mol Biol 192 (3): 503-511.

Buonnacorsi VP, McDowell JR, Graves JE. 2001. Reconciling patterns of inter-ocean molecular variance from four classes of molecular markers in blue marlin (Makaira nigricans). Mol Ecol 10: 1179-1196.

Carpenter KE, Barber PH, Crandall ED, Ablan-Lagman MCA, Ambariyanto, Mahardika GN, Matsumoto BMM, Juinio-Meñez, MA, Santos MD, Starger CJ, Toha AHA. 2011. Comparative phylogeography of the Coral Triangle and implications for Marine Management. J Mar Biol 2011: 1-14.

Chiang H, Hsu C, Lin H, Ma GC, Chiang T, Yang H. 2006. Population structure of bigeye tuna (Thunnus obesus) in the South China Sea, Philippine Sea and western Pacific Ocean inferred from mitochondrial DNA. Fish Res 79: 219-225.

Chiang H, Hsua C, Wu GC, Chang S, Yang H. 2008. Population structure of bigeye tuna (Thunnus obesus) in the Indian Ocean inferred from mitochondrial DNA. Fish Res 90: 305-312.

Chow S, Okamoto H, Miyabe N, Hiramatsu K, Barut N. 2000. Genetic divergence between Atlantic and Indo-Pacific stocks of bigeye tuna (Thunnus obesus) and admixture around South Africa. Mol Ecol 9 (2): 221-227.

Collette BB, Carpenter KE, Polidoro BA, Juan-Jorda MJ, Boustany A, Die DJ, Elfes C. Fox W, Graves J, Hsrrison LR, McManus R, Minte-Vera
CV, Nelson R, Restrepo V, Schratwieser J, Sun CL, Amorim A, Peres MB, Canales C, Cardena G, Chang SK, Chiang WC, Leite NOJ, Harwell H, Lessa R, Fredou FL, Oxendorf HA, Serra R, Shao KT, Sumaila R, Wong SP, Watson R, Yáñez E. 2011. High value and long life - double jeopardy for tunas and billfishes. Science 333 (6040): 291-292.

Dickson OJ, Natividad AC. 2000. Tuna fishing and a review of payaos in the Phillippines. In: Pêche thonière et dispositifs de concentration de poissons [Internet]. Caribbean-Martinique; [141-58]. Available at http://archimer.ifremer.fr/doc/00042/15284/12670.pdf, access date 1 March, 2016

Excoffier L, Laval G, Schneider S. 2005. Arlequin (version 3.0): an integrated software package for population genetics data analysis. Evolutionary Bioinformatics online 1: 47-50.

Excoffier L, Lischer HE. 2010. Arlequin suite ver 3.5 a new series of programs to perform population genetics analyses under Linux and Windows. Mol Ecol Resour 10 (3): 564-567.

Excoffier L, Smouse PE, Quattro JM. 1992. Analysis of molecular variance inferred from metric distances among DNA haplotypes: application to human mitochondrial DNA restriction data. Genetics 131 (2): 479-491.

FAO. 2000. Biological characteristics of tuna. FAO Fisheries and Aquaculture Department, Rome.

FAO Fisheries. 2013. TUNA A global perspective. Fisheries and Aquaculture Department, Food and Agriculture Organization of the United Nations (FAO), Rome.

Gonzalez EG, Beerli P, Zardoya R. 2008. Genetic structuring and migration patterns of Atlantic bigeye tuna, Thunnus obesus (Lowe, 1839). BMC Evol Biol 8: 252.

Guo SW, Thompson EA. 1992. Performing the exact test of HardyWeinberg proportion for multiple alleles. Biometrics 48 (2): 361-372.

Jackson AM, Ambariyanto, Erdmann MV, Toha AHA, Stevens LA, Barber PH. 2014. Phylogeography of commercial tuna and mackerel in the Indonesian Archipelago. Bull Mar Sci 90 (1): 471-492.

Juan-Jorda MJ, Mosqueira I, Cooper AB, Freire J, Dulvy NK. 2011. Global population trajectories of tunas and their relatives. Proc Natl Acad Sci USA 108 (51): 20650-20665.

Juan-Jorda MJ, Mosqueira I, Freire J, Dulvy NK. 2013. The conservation and management of tunas and their relatives: setting life history research priorities. PloS one. doi: 10.1371/journal.pone.0070405.

Kimura M. 1980. A simple method for estimating evolutionary rates of base substitutions through comparative studies of nucleotide sequences. J Mol Evol 16 (2): 111-120.

Kumar G, Kocour M, Kunal SP. 2014. Mitochondrial DNA variation and phylogenetic relationships among five tuna species based on sequencing of D-loop region. Mitochondrial DNA 2014: 1-5. DOI: 10.3109/19401736.2014.971313

Lee WJ, Conroy J, Howell WH, Kocher TD. 1995. Structure and evolution of teleost mitochondrial control regions. J Mol Evol 41 (1): 54-66.

Librado P, Rozas J. 2009. DnaSP v5: a software for comprehensive analysis of DNA polymorphism data. Bioinformatics 25 (11): 14511452.

Lynch M, Crease TJ. 1990. The analysis of population survey data on DNA sequence variation. Mol Biol Evol 7 (4): 377-394.

Macusi ED, Babaran RP, van Zwieten PAM. 2015. Strategies and tactics of tuna fishers in the payao (anchored FAD) fishery from general Santos city, Philippines. Mar Pol 62: 63-73.

Martinez P, Gonzalez EG, Castilho R, Zardoya R. 2006. Genetic diversity and historical demography of Atlantic bigeye tuna (Thunnus obesus). Mol Phylogenet Evol 39 (2): 404-416.

Miyake MP, Guillotreau P, Sun C-H, Ishimura G. 2010. Recent development in the tuna industry: stocks, fisheries, management, processing, trade and markets. FAO, Rome.

Nei M, Stephens JC, Saitou N. 1985. Methods for computing the standard errors of branching points in an evolutionary tree and their application to molecular data from humans and apes. Mol Biol Evol 2 (1): 66-85.

Qiu F, Kitchen A, Beerli P, Miyamoto MM. 2013. A possible explanation for the population size discrepancy in tuna (genus Thunnus) estimated from mitochondrial DNA and microsatellite data. Mol Phylogenet Evol 66 (2): 463-468.

Saitou N, Nei M. 1987. The neighbor-joining method: a new method for reconstructing phylogenetic trees. Mol Biol Evol 4 (4): 406-425.

Sibert J, Senina I, Lehodey P, Hampton J. 2012. Shifting from marine reserves to maritime zoning for conservation of Pacific bigeye tuna (Thunnus obesus). Proc Natl Acad Sci USA 109 (44): 18221-18225. 
Sunoko R, Huang HW. 2014. Indonesia tuna fisheries development and future strategy. Mar Pol 43: 174-183.

Tamura K, Nei M.1993. Estimation of the number of nucleotide substitutions in the control region of mitochondrial-DNA in humans and chimpanzees. Mol Biol Evol 10 (3): 512-526.

Tamura K, Stecher G, Peterson D, Filipski A, Kumar S. 2013. MEGA6. Molecular Evolutionary Genetics Analysis version 6.0. Mol Biol Evol 30 (12): 2725-2729.
Walsh PS, Metzger DA, Higushi R. 1991. Chelex 100 as a medium for simple extraction of DNA for PCR-based typing from forensic material. BioTechniques 10 (4): 506-513.

Weir BS, Hill WG. 2002. Estimating F-statistics. Annu Rev Genet 36: 721-750. 
Table S1. The result of Fst test between locations of bigeye tuna samples from Indonesia

\begin{tabular}{|c|c|c|c|c|c|c|c|c|c|}
\hline & $\begin{array}{c}\text { Indian } \\
\text { Ocean } \\
\text { Java }\end{array}$ & Lombok & Manokwari & $\begin{array}{c}\text { South } \\
\text { Sulawesi }\end{array}$ & $\begin{array}{c}\text { North } \\
\text { Sulawesi }\end{array}$ & $\begin{array}{c}\text { Indian } \\
\text { Ocean } \\
\text { Bungus }\end{array}$ & $\begin{array}{l}\text { West } \\
\text { Java }\end{array}$ & Ambon & $\begin{array}{c}\text { North } \\
\text { Maluku }\end{array}$ \\
\hline \multicolumn{10}{|l|}{ Indian Ocean Java } \\
\hline Lombok & - & & & & & & & & \\
\hline Manokwari & - & - & & & & & & & \\
\hline South Sulawesi & - & - & - & & & & & & \\
\hline North Sulawesi & - & - & - & - & & & & & \\
\hline Indian Ocean Bungus & - & - & - & - & - & & & & \\
\hline West Java & - & - & - & - & - & - & & & \\
\hline Ambon & - & + & - & - & - & - & - & & \\
\hline North Maluku & - & - & - & - & + & - & - & - & \\
\hline Muara Baru & - & - & - & - & - & - & - & - & - \\
\hline
\end{tabular}

Note: Positive (+) or negative (-) mean significant or not-significant differentiation. 